\title{
P297: Increasing needle stick injuries amongst the radiology team-needs attention!
}

\author{
A Ghafur ${ }^{*}$, PR Vidyalakshmi, K Chandra, P Kannaian, J Sahaya \\ From 2nd International Conference on Prevention and Infection Control (ICPIC 2013) \\ Geneva, Switzerland. 25-28 June 2013
}

\section{Introduction}

Needle-stick injuries and blood contacts pose a risk of pathogen transmission during invasive procedures. As interventional radiological procedures for diagnostics and therapeutics are on rise, reinforcing importance of sharp disposal in this population is mandatory.

\section{Objectives}

Analysis of the vulnerable area for needle stick injuries.

\section{Methods}

Analysis of 24 month data of needle stick injury as documented by the hospital infection control committee from a neurosurgical and oncology tertiary care hospital in Chennai, South India.

\section{Results}

Twenty one needle stick injuries were documented in the last two years. Six of them were doctors and nurses, 4 were radiology technicians and 4 were ward assistants and 1 was a phlebotomist. Five episodes occurred on venepunture 4 were following biopsy and four while clearing clinical waste, 5 during line insertion. Four of the sources were positive for blood borne viruses, two were HIV positive one $\mathrm{HCV}$ and one hepatitis B. All the patients received Post exposure prophylaxis at the earliest (2 ART,1 Booster with Hepatitis B vaccine).None of them had seroconversion on follow up. Needle stick injuries occurred most commonly during radiological procedures (33.3\%) and in the CCU (33.3\%).

\section{Conclusion}

As interventional radiological procedures are increasing, this area along with the CCU needs to be targeted for CME or educational interventions.

Infectious diseases, Apollo speciality hospitals, Chennai, India

\section{Competing interests}

None declared.

Published: 20 June 2013

doi:10.1186/2047-2994-2-S1-P297

Cite this article as: Ghafur et al:: P297: Increasing needle stick injuries amongst the radiology team-needs attention!. Antimicrobial Resistance and Infection Control 2013 2(Suppl 1):P297.
Submit your next manuscript to BioMed Central and take full advantage of:

- Convenient online submission

- Thorough peer review

- No space constraints or color figure charges

- Immediate publication on acceptance

- Inclusion in PubMed, CAS, Scopus and Google Scholar

- Research which is freely available for redistribution

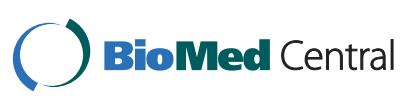

(c) 2013 Ghafur et al; licensee BioMed Central Ltd. This is an Open Access article distributed under the terms of the Creative Commons Attribution License (http://creativecommons.org/licenses/by/2.0), which permits unrestricted use, distribution, and reproduction in any medium, provided the original work is properly cited. 